\title{
Resource-Saving Technology for the Gathering, Treatment and Injection of Oil-Field Water
}

\author{
Vyacheslav Gusev, Alexandra Kichigina, Emil Kharasov, Oleg Gorbunov \\ Samara State Technical University, Samara, Russian Federation
}

doi: https://doi.org/10.21467/abstracts.93.96

\begin{abstract}
ABST RA C T
The oil and gas industry holds a leading position in the economy of the Russian Federation. Intensive activity in hydrocarbon production poses risks of disturbance of ecological balance and is accompanied by emergency situations. The main environmental problems arising in the process of oil production are associated with the occurrence of emergency situations during the operation of infield pipelines. Emergency situations arising at oilfield pipelines cause serious environmental problems as they are associated with the release of a significant amount of pollutants into the environment, air and water pollution and the formation of oil-contaminated soil.

In 2019 oil production in the Russian Federation reached a record volume - 560.26 million tons [1] (about 630.0 million $\mathrm{m} 3$ ). This production was $90 \%$ ensured by the exploitation of deposits that have been in operation for more than 25 years (Romashkinskoye, Arlanskoye, Samotlor, Mamontovskoye, Fedorovskoye, Megionskoye, Pokachevskoye, etc.). At the same time, the average water cut of the produced well products is $90 \%$ or more. Thus, oil companies while extracting 630.0 million $\mathrm{m} 3$ of oil extracted at least 3 billion 800 million $\mathrm{m} 3$ of oil-field water which after separation from oil and treatment was injected back into the formation.

The design and facilities construction of the main part of the Russian oil fields was carried out more than 20 years ago and was calculated on the existing level of oil production at that time. Due to the advanced commissioning of the fields the equipment location was designed with the insufficient geological study of the work area and, as a rule, was placed in the central zones of the fields. The initial development period characterized by low water cut smoothed out all the drawbacks of technological schemes of field development.

In the process of development and subsequent research the area of the oil fields increased by 2-3 times. The required level of oil production was provided by forced production of liquid and the volume of associated water increased 4 times since 1995 and amounted to 3.8 billion $\mathrm{m} 3$ in 2019. This was accompanied by a natural increase in water cut of extracted products, which reached $86-92 \%$. With the growth of water cut in well products the aggressive corrosion zone in field pipelines increased and operating costs and energy consumption increased accordingly. Only for the last 7 years, the cost of oil production in the Russian Federation has doubled (from 7491.9 rubles per ton to 14942.94 rubles per ton) [3].

All field pipelines have received excessive loads because, over the last 10 years, the volume of oil-field water production doubled and the capacity of the existing pipeline system has not changed. Forced liquid production also leads to an increase in the equipment load on the existing preliminary water removal unit and oil treatment plants. Prolong operation of field piping systems, their high wear and tear have formed the conditions for increasing the accident rate of their operation, increased the risks of leaks as well as accident rate of oil, gas and water treatment equipment mainly due to internal and external corrosion of the metal.
\end{abstract}

(C) 2020 Copyright held by the author(s). Published by AIJR Publisher in "Abstracts of The Second Eurasian RISK-2020 Conference and Symposium" April 12- 19, 2020, Tbilisi, Georgia. Jointly organized by AMIR Technical Services LLC, Georgian Technical University, Institute of Geography (Kazakhstan) and Russian Institute of Petroleum Geology and Geophysics.

AijR DOI: $10.21467 /$ abstracts.93 
The Second Eurasian RISK-2020 Conference and Symposium

With a total length of field pipelines of all types of about 220 thousand $\mathrm{km}$ the number of leaks in field pipelines only in 2018 was about 30 thousand or, on average, one leak per $7.1 \mathrm{~km}$. According to the data provided by the Ministry of Energy of the Russian Federation, in 2018 there were 8,126 leakages with oil spills and environmental pollution in the amount of at least 1.0 million tons, of which 7,017 leakages in the oil pipelines $(90 \%)$ occurred because of corrosion. The social and economic damage is estimated at about 500 billion rubles. According to the Ministry of Natural Resources and Ecology of the Russian Federation estimation, the replacement of field pipelines should be $7-12 \%$ per year (about 20 thousand $\mathrm{km}$ ), of the total length, and in fact $1-2 \%$ (about 3.0 thousand $\mathrm{km}$ ) is replaced. This creates extremely unfavorable social and environmental conditions in the areas of oil production.

The novelty of the proposed solution lies in the discharge of oil-field water directly on the well clusters or at a short distance from them by means of modular water treatment and injection facilities. This decision will significantly decrease the risk of environmental pollution by reducing the volume of pumped liquid, and reduce the load on the main oil treatment facilities and the number of vertical tanks.

Electricity consumption for transporting water from treatment units to reservoir pressure maintenance system facilities are also significantly reduced. By discharging associated water near the wells, the length of the pipelines of reservoir pressure maintenance system is reduced from $24.8 \mathrm{~km}$ to $13.9 \mathrm{~km}$, and metal consumption is reduced by $44 \%$. Due to the reduced volume of pumped liquid, it becomes possible to replace existing pipes with polymer-metal pipes with a smaller diameter which will significantly reduce the metal consumption of field pipelines and the cost of their repair.

The replacement of steel pipes with polymer-metal pipes will reduce the risk of the environment contamination as the low electrical conductivity of polymer materials included in the design of polymermetal pipes eliminates the possibility of stray currents in them and associated corrosion damage to the pipelines. There is no need for an electrochemical protection device, which also reduces the costs of both the proposed reconstruction and subsequent operating costs. The period of trouble-free operation of steel pipelines in aggressive environments is 3-5 years, and the accident rate reaches 30 or more accidents per 1 $\mathrm{km}$ per year. Polymer-metal pipes can be safely operated for 20 years or more.

To ensure environmental safety it is necessary to have an automated system to control technological processes and technical condition of equipment and pipelines which is part of an automated field monitoring system. The monitoring system will allow to quickly influence technological processes, to control the dynamics of excessive pressure and temperature, the presence or absence of defects and on the basis of received information analysis to predict the occurrence of critical defects as well as the period of troublefree maintenance of pipelines and equipment.

\section{References}

[1] Ministry of Energy of the Russian Federation // Crude oil production statistics including gas condensate for the period 01/01/2019 - 12/31/2019 // URL: https://minenergo.gov.ru/activity/statistic (Date of visit: 02/10/2020).

[2] Ministry of Energy of the Russian Federation // Information on the volume of electricity generation in Russia // URL: https://minenergo.gov.ru/opendata/7705847529-vyrabotkaenergy (Date of visit: 02/10/2020).

[3] Federal State Statistics Service // Technological development of industries. Energy Efficiency Indicators. Cost of oil production. // URL: https://gks.ru/folder/11189 (Date of visit: 02/08/2020). 